2loolf 2laft

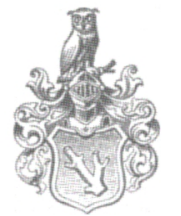

65. I. (5öfdyen'fhe

Derlagshandung.

Begr. 1285. 



\section{Gimilia Balntti.}

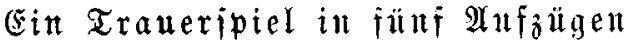

won

Gotth. Ephr. Reifing.

$$
\mathfrak{E} \mathfrak{i} \mathfrak{i} \mathfrak{i} \mathfrak{g} \text {. }
$$

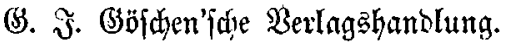

1867. 


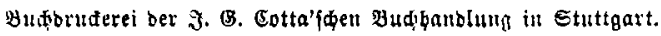

